\title{
Pengaruh Kedisplinan Guru Terhadap Hasil Belajar Siswa Kelas V SD YPPGI Guopaka, Distrik Tiom, Kab. Lanny Jaya Papua
}

\author{
Juarni Gea, ${ }^{1}$ Efvi Noyita ${ }^{2}$ \\ Prodi PAK, STT Real Batam
}

\begin{abstract}
The teacher's role is key to the functioning of a school education institution. Teachers have enormous responsibility in an effort to deliver their students to the educational goals they aspire to. In this case the teacher is responsible for meeting the needs of his students, both spiritual, moral, aesthetic, and physical needs of each student. Therefore, a teacher must be able to behave properly and well in every way, especially in terms of discipline. Discipline is one very important aspect of the learning process. Without discipline, the predetermined learning targets cannot be achieved optimally. This study aims to determine whether there is an effect of teacher discipline on learning outcomes at SD YPPGI Guopaka, Tiom district, Lanny Jaya Papua district. In this study the authors used data analysis techniques with data processing using the SPSS (Statistical Package for Social Science) program with the hope that all the data that has been obtained has met the requirements to conclude the results of a study. The results of the research conducted stated, "that teacher discipline has a positive effect on student learning outcoME.
\end{abstract}

Keywords: Influence, Discipline, Teacher, Learning Outcomes, Students."

\begin{abstract}
Abstrak
Peran guru adalah kunci bagi berfungsinya sebuah lembaga pendidikan sekolah. Guru memilki tanggung jawab yang sangat besar dalam upaya mengantarkan para peserta didiknya kepada tujuan pedidikan yang dicita-citakan. Dalam hal ini Guru bertanggung jawab memenuhi kebutuhan peserta didiknya, baik spiritual, moral, estetika, maupun kebutuhan fisik setiap peserta didiknya. Oleh karenanya seorang guru haruslah mampu berperilaku benar dan baik dalam setiap hal, terutama dalam hal kedisplinan. Kedisplinan merupakan salah satu aspek yang sangat penting dalam proses pembelajaran. Tanpa ada kedisplinan maka target pembelajaran yang sudah ditentukan sebelumnya tidak dapat tercapai dengan maksimal. Penelitian ini bertujuan mengetahui apakah terdapat pengaruh kedisplinan guru terhadap hasil belajar di SD YPPGI Guopaka distrik Tiom, Kabupaten Lanny Jaya Papua. Dalam penelitian ini penulis menggunakan teknik analisa data dengan proses pengolahan datanya menggunakan bantuan program SPSS (Statistical Package for Social Science) dengan harapan bahwa seluruh data yang telah diperoleh telah memenuhi syarat untuk menyimpulkan hasil dari sebuah penelitian. Hasil penelitian yang dilakukan menyatakan, "bahwa kedisplinan guru berpengaruh positif terhadap hasil belajar peserta didik."

Kata-kata kunci: Pengaruh, Kedisplinan, Guru, Hasil Belajar, Siswa
\end{abstract}

\section{PENDAHULUAN}

Secara garis besar adapun faktor-faktor yang mempengaruhi hasil belajar menurut Ngalim Purwanto terdiri dari dua faktor yaitu faktor internal dan faktor eksternal. Pertama. Faktor internal adalah faktor yang berasal dari dalam diri siswa antara lain faktor fisiologi seperti fisiologis dan kondisi panca indra. Faktor psikologis seperti intelegensi, perhatian, minat, bakat motif, kematangan dan kesiapan. Kedua. Faktor eksternal yaitu faktor yang berasal dari luar diri siswa, antara lain faktor lingkungan seperti alam dan sosial.

Faktor-faktor yang mempengaruhi hasil belajar, terlihat jelas bahwa guru merupakan salah satu faktor penting dalam menemukan hasil belajar siswa. Dalam mengajar guru tidak hanya dituntut untuk memberikan pengajaran dari aspek kognitif 
saja, melainkan mampu memberikan pengajaran sikap yang dapat membina siswa agar dapat menjadi manusia yang berwatak (berkarakter) dan mampu menciptakan kebiasaan, sikap, cita-cita, berfikir hebat, berani dan tanggung jawab dan bertindak atas dasar nilai moral yang tinggi.

Hal diatas menunjukkan bahwa seorang guru hendaknya memiliki kepribadian atau tingkah laku yang bisa menjadi contoh kongkrit bagi para peserta didiknya yang mencakup segala aspek termasuk sikap displin. Displin yang dimaksud adalah displin dalam mengajar. Hal ini sangat penting bagi seorang guru, karena displin dalam mengajar merupakan hal yang sangat menentukan dalam proses pencapaian tujuan pendidikan.

\section{METODE}

Penelitian ini menggunakan teknik analisa data dengan bantuan program SPSS (Statistical Package for Social Science) dengan harapan bahwa seluruh data yang telah diperoleh memenuhi syarat untuk menyimpulkan hasi dari sebuah penelitian. Tahapan analisa data dimulai dengan menyusun keseluruhan data dari pernyataan-pernyataan yang ada dalam kuesioner yang telah dibagikan di SD YPPGI Guopaka kelas kurang VA dan VB dan kemudian menghitung rata-rata, variasi dan diakhiri dengan korelasi maupun regresi. Dengan analisa data dapat diperoleh gambaran menyeluruh tentang semua data yang telah diperoleh. Populasi dalam penelitian ini adalah kelas VA dan VB di SD YPPGI Guwopaka yang berjumlah 30 orang Populasi adalah kumpulan dari keseluruhan pengukuran, objek atau individu yang sedang dikaji. ${ }^{1}$

\section{HASIL DAN PEMBAHASAN}

\section{Pengertian Belajar}

Menurut Howard L. Kingsleny mendefinisikan belajar sebagai learning is the process by which behavior (in the broader sense) is originated or changed through practice or training (belajar adalah proses ketika tingkah laku (dalam arti luas) ditimbulkan atau diubah melalui praktik atau latihan).

Selanjutnya American Heritage Psychology secara lebih luas memerinci belajar sebagai :

a. To gain knowledge, comprehension, or mastery through experience or study (bertambahnya pengetahuan dan keahlian melalui pengalaman belajar).

b. To fix in the mind or memory: memorize (perpaduan antara berpikir dan mengingat, menghafalkan).

c. To acquire through experience, kesiapan untuk memperoleh pengalaman. ${ }^{2}$

Dalam kamus besar bahasa Indonesia pengertian belajar adalah berusaha memperoleh kepandaian atau ilmu. Seseorang dikatakan belajar jika dalam diri orang tersebut terjadi suatu proses kegiatan yang mengakibatkan suatu perubahan tingkah laku. Menurut Robert M. Gagne belajar adalah perubahan yang terjadi dalam kemampuan manusia yang terjadi setelah belajar terus-menerus, bukan hanya disebabkan proses pertumbuhan saja. Selanjutnya Harold Spears mengatakan belajar adalah mengamati, membaca, meniru, mecoba sendiri tentang sesuatu, mendengarkan,

1 Harinald M. Eng, Prinsip-Prinsip Statistik untuk Teknik Dan Sains, (Hak Cipta: Erlangga, 2005), hlm 2

2 H.Baharuddin, Pendidikan \& Psikologi Perkembangan, Ar-Ruzz Media, 2012, hlm. 161-163 
mengikuti petunjuk, maupun dalam hal bidang keterampilan atau kecakapan. Made Pidarta juga menjelaskan belajar adalah perubahan perilaku yang relative permanen sebagi hasil pengalaman (bukan hasil perkembangan, pengaruh, obat, atau kecelakaan) dan bila melaksanakannya pada pengetahuan lain serta mampu mengkomunikasikannya kepada orang lain. ${ }^{3}$

Jadi dapat peneliti simpulkan, bahwa belajar adalah suatu syarat yang tidak dapat dirubah dalam mencapai tingkat pemahaman yang tinggi dalam berbagai macam hal, baik dalam keilmuan maupun dalam hal seni atau keterampilan.

\section{Prinsip-Prinsip Belajar}

Menurut Suprijono (2009:4-5), prinsip-prinsip belajar terdiri dari tiga hal. Pertama, prinsip belajar adalah prubahan perilaku sebagai hasil belajar yang memiliki ciri-ciri sebagai berikut :

1. sebagai hasil tindakan rasional instrumental, yaitu perubahan yang disadari.

2. kontinu atau berkesinambungan dengan perilaku lainnya.

3. fungsional atau bermanfaat sebagai bekal hidup.

4. posotif atau berakumulasi.

5. aktif sebagai usaha yang direncanakan dan dilakukan.

6. permanen atau tetap.

7. bertujuan terarah.

8. mencakup keseluruhan poeansi kemanusiaan.

\section{Hasil Belajar}

Menurut Hamzah B. Uno, "Hasil belajar adalah perubahan perilaku yang relatif menetap dalam diri seseorang sebagai akibat dari interaksi seseorang dengan lingkungannya." 4

Dimyati dan Mudjiono dalam bukunya "Belajar dan Pembelajaran" menyebutkan bahwa hasill belajar adalah proses untuk menentukan nilai belajar siswa melalui kegiatan penilaian atau pengukuran hasil belajar. ${ }^{5}$

Untuk mengetahui perkembangan sampai di mana hasil yang telah dicapai oleh seseorang dalam belajar, maka harus dilakukan evalusi. Untuk menentukan kemampuan yang dicapai maka harus ada kriteria atau patokan yang mengaju pada tujuan yang telah ditentukan sehingga dapat diketahui seberapa besar pengaruh strategi belajar mengajar terhadap keberhasilan belajar siswa. Hasil belajr siswa menurut W. Winkel adalah

${ }^{333}$ Made pidarta, Landasan Pendidikan : Stimulus IImu Pendidikan Bercorak Indonesia,

(Jakarta:Rineka Cipta,2009), hlm. 206.

3 Hamzah B. Uno, model Pembelajaran : Menetapkan Proses Belajar Mangajar yang Kreatif dan Efektif, (Jakarta:PT. Bumi Aksara,2008), hlm 211

4 Dimyati, Mudjiono, Belajar dan Pembelajaran, (Jakarta:Rineka Cipta,2009),hlm. 200

5 W. Winkel, Psikologi Pengajaran, ( Jakarta: Gramedia, 1989), hlm. 82 
"keberhasilan yang dicapai oleh siswa yakni prestsi bel' ${ }^{6}$ ajar siswa di sekolah yang diwujudkan dalam bentuk angka." 7

\section{Macam-Macam Hasil Belajar}

Hasil belajar sebagaimana diatas telah disampaikan meliputi pemahaman konsep (Aspek kognitif), proses keterampilan (Aspek Psikomotorik), dan sikap siswa (Aspek Afektif). Untuk lebih jelasnya dapat dijelaskan sebagai berikut:

Dapat peneliti simpulkan, bahwa macam-macam dari hasil belajar meliputi beberapa aspek. Yakni aspek kognitif atau pemahaman konsep. Pemahaman konsep merupakan sejauh mana siswa mengerti atau paham dengan gambaran atau gagasan yang telah diberikan oleh guru kepada siswa. Selanjutnya, keterampilan proses (aspek psikomotorik) suatu kemampuan dalam menumbuhkan mental, fisik dan sosial yang ada pada diri setiap siswa dengan menggunakan daya nalar yang dimilili oleh siswa. Selanjutnya lagi adalah sikap siswa (aspek afektif). Sikap siswa dilakukan atas dorongan dari dalam jiwa siswa yang berperan sebagai penggerak dalam menghasilkan proses belajar yang baik.

\section{Faktor-Faktor Yang Mempengaruhi Hasil Belajar}

Dapat peneliti simpulkan bahwa faktor-faktor yang mempengaruhi hasil belajar meliputi, kecerdasan anak, tingkat kemampuan siswa dalam menyerap berbagai ilmu yang telah ditransferkan oleh guru sangat berpengaruh dalam pencapaian hasil belajar siswa. Semakin cepat kemampuan siswa dalam belajar maka semakin baik pula hasil yang dicapai sesuai dengan tujuan yang ditentukan. Selanjutnya terdapat pada kesiapan atau kematangan. Dalam kesiapan dan kematangan siswa ini sangat berpengaruh dengan hasil belajar siswa,.

Demikian juga menurut Muhibbin Syah, faktor-faktor yang mempengaruhi belajar peserta didik antara lain: (1) Faktor internal meliputi dua aspek yaitu aspek fisiologi dan aspek psikologi, (2) Faktor eksternal meliputi: faktor lingkungan sosial dan faktor lingkungan nonsosial.

Faktor utama yang mempengaruhi hasil belajar siswa antara lain:

1. Faktor internal yakni keadaan/ kondisi jasmani dan rohani peserta didik.

2. Faktor eksternal (faktor dari luar siswa), yakni kondisi lingkungan disekitar peserta didik mesilanya faktor lingkungan.

3. Faktor pendekatan belajar yakni jenis upaya belajar siswa yang meliputi strategi dan metode yang digunakan untuk melakukan kegiatan mempelajari materi-materi pembelajaran. ${ }^{8}$

8 Muhibbin Syah,psikologi pendidikan dengan pendekatan baru (PT Remaja Rosdakarya, 1999) hlm. 132

7 Sudarwin Danim, Pengembangan Profesi Guru: dari Pra Jabatan Induksi, (Jakarta: Premada Media group, 2012), 


\section{Manfaat Hasil Belajar}

hasil belajar harus menunjukkan perubahan keadaan menjadi lebih baik, sehingga bermanfaat untuk : (a) menambah pengetahuan, (b) lebih memahami sesuatu yang belum dipahami sebelumnya, (c) lebih mengembangkan keterampilannya, (d) memiliki pandangan yang baru atas sesuatu hal, (e) lebih mengargai sesuatu daripada sebelumnya. Dapat disimpulkan bahwa istilah hasil belajar merupakan perubahan dari siswa sehingga terdapat perubahan dari segi pengetahuan, sikap dan keterampilan.

\section{Kedisplinan guru}

Kata dasar kedisplinan adalah "displin" yang berarti ketaatan pada peraturan. ${ }^{9}$ Istilah disiplin berasal dari bahasa Inggis "discipline" yang mengandung beberapa arti diantaranya adalah pengendalian diri, membentuk karakter yang bermoral, memperbaiki dengan sanksi, serta kumpulan beberapa tata tertib untuk mengatur tingkah laku.

Displin sangat berkaitan erat dalam proses pelatihan yang dilakukan oleh pihak yang memberi pengarahan dan bimbingan dalam kegiatan pengajaran. Displin juga bisa membentuk karakter seseorang, baik itu karakter yang baik, atau karakter yang tidak baik, dengan displin karakter yang baik itu akan muncul dengan sendirinya tanpa ada dorongan dari dalam atau dari luar diri seseorang. Dapat disimpulkan bahwa kedisplinan adalah sebuah peraturan yang harus dipatuhi dan dilaksanakan oleh setiap orang (individu) dalam menjalankan kewajibannya sesuai dengan profesinya masing-masing serta adanya kesadaran dan dorongan dalam diri.

Menurut Sudarwan Danim dalam bukunya bahwa ada beberapa pesan bagi orang yang menghargai waktu yaitu: ${ }^{7}$ (a) Mengajarlah pada waktu mengajar, (b) Tidurlah pada waktu tidur, (c) Bekerjalah pada waktu bekerja, (c) Berbicaralah pada waktu berbirara, (d) Menjadi pendengarlah pada waktu harus mendengarkan, (e) Hadirlah sesuai dengan jadwal yang telah ditetapkan, (f) Penuhilah semua persyaratan atau kewajiban yang diharuskan, (g) Berkonsentrasilah pada saat bekerja atau belajar.

\section{Kerangka berpikir :}

$\mathrm{X}$ (variabel bebas) : kedisplinan guru

Y (variabel terikat) : hasil belajar peserta didik

R: Pengaruh kedisplinan guru terhadap hasil belajar peserta didik

$\mathrm{r}_{1}$ : Pengaruh datang tepat waktu terhadap hasil belajr peserta didik

$\mathrm{r}_{2}$ : Pengaruh pelaksanaan tugas terhadap hasil belajar

$\mathrm{r}_{3}$ : Pengaruh pogram tidak lanjut terhadap hasil belajar peserta didik

$\mathrm{r}_{4}$ : Pengaruh bertanggung jawab terhadap hasil belajar peserta didik

\section{Hipotesa}

Berdasarkan kajian teori diatas maka rumusan hipotesis yaitu adanya pengaruh yang sigfinikan antara kedisplinan guru terhadap hasil belajar kelas VA dan VB di SD YPPGI Guopaka, tidak ada. 


\section{Uji validitas}

Tujuan dari pengujian validitas adalah untuk mengukur ketetapan instrument yang digunakan dalam suatu penelitian. Dasar pengambilan keputusan uji Validitas dengan menggunakan Pearson Produtct Moment adalah dengan membandingkan nilai $\mathbf{r}_{\text {hitung }}$ dengan $\mathbf{r}_{\text {tabel }}$

1. Jika nilai $\mathbf{r}_{\text {hitung }}>\mathbf{r}_{\text {tabel }}=$ valid

2. Jika nilai $\mathbf{r}_{\text {hitung }}<\mathbf{r}_{\text {tabel }}=$ tidak valid

Adapun hasil nilai $\mathbf{r}_{\text {tabel }}$ dengan $\mathbf{N}=\mathbf{7 1}$ pada signifikasi $5 \%$ pada distribusi nilai $\mathbf{r}_{\text {tabel }}$ statistic, adalah memperoleh nilai $\mathbf{r}_{\text {tabel }}$ sebesar $\mathbf{0 . 2 3}$. Hasil uji validitas untuk soal kuesioner dari masing-masing variabel penelitian adalah sebagai berikut:

Tabel uji validitas variabel $Y$

\begin{tabular}{|c|c|c|c|c|}
\hline Nomor Soal & $\mathbf{r}_{\text {hitung }}$ & $\mathbf{r}_{\text {tabel }} \mathbf{5 \% ( 3 0 )}$ & Sig. & Kriteria \\
\hline Y.1 & 0.598 & 0.439 & 0.000 & Valid \\
\hline Y.2 & 0.744 & 0.439 & 0.000 & Valid \\
\hline Y.3 & 0.446 & 0.439 & 0.014 & Valid \\
\hline Y.4 & 0.586 & 0.439 & 0.001 & Valid \\
\hline Y.5 & 0.589 & 0.439 & 0.001 & Valid \\
\hline Y.6 & 0.711 & 0.439 & 0.000 & Valid \\
\hline Y.7 & 0.468 & 0.439 & 0.009 & Valid \\
\hline Y.8 & 0.431 & 0.439 & 0.017 & Valid \\
\hline Y.9 & 0.611 & 0.439 & 0.000 & Valid \\
\hline
\end{tabular}

Tabel uji validitas variabel $X$

\begin{tabular}{|c|c|c|c|c|}
\hline Nomor Soal & $\mathbf{r}_{\text {hitung }}$ & $\mathbf{r}_{\text {tabel }} \mathbf{5 \% ( 3 0 )}$ & Sig. & Kriteria \\
\hline X.10 & 0,344 & 0.349 & 0.063 & Valid \\
\hline X.11 & 0.605 & 0.349 & 0.000 & Valid \\
\hline X.12 & 0.475 & 0.349 & 0.008 & Valid \\
\hline X.14 & 0.619 & 0.349 & 0.000 & Valid \\
\hline X.15 & 0.685 & 0.349 & 0.000 & Valid \\
\hline X.16 & 0.360 & 0.349 & 0.051 & Valid \\
\hline X.17 & 0.481 & 0.349 & 0.007 & Valid \\
\hline X.18 & 0.591 & 0.349 & 0.001 & Valid \\
\hline X.19 & 0.450 & 0.349 & 0.013 & Valid \\
\hline X.20 & 0.615 & 0.349 & 0.000 & Valid \\
\hline
\end{tabular}

Tabel Hasil Uji Realibilitas

\begin{tabular}{|c|c|c|c|}
\hline Variabel & Cronbach's Alpha & Keterangan & Kriteria \\
\hline Kedisplinan guru $(\mathrm{X})$ & 0.691 & $>0.60$ & Reliabel \\
\hline Hasil Belajar $(\mathrm{Y})$ & 0.748 & $>0.60$ & Reliabel \\
\hline
\end{tabular}

Sumber: Data Primer diolah Maret 2019

Nilai cronbach's Alpha dari masing-masing variabel penelitian baik itu variabel $\mathrm{x}$ maupun variabel $\mathrm{Y}$ menunjukkan hasil yang lebih besar dari 0.60 , hal ini dapat disimpulkan bahwa soal pernyataan dari masing-masing variabel adalah reliable. 


\section{Uji normalitas}
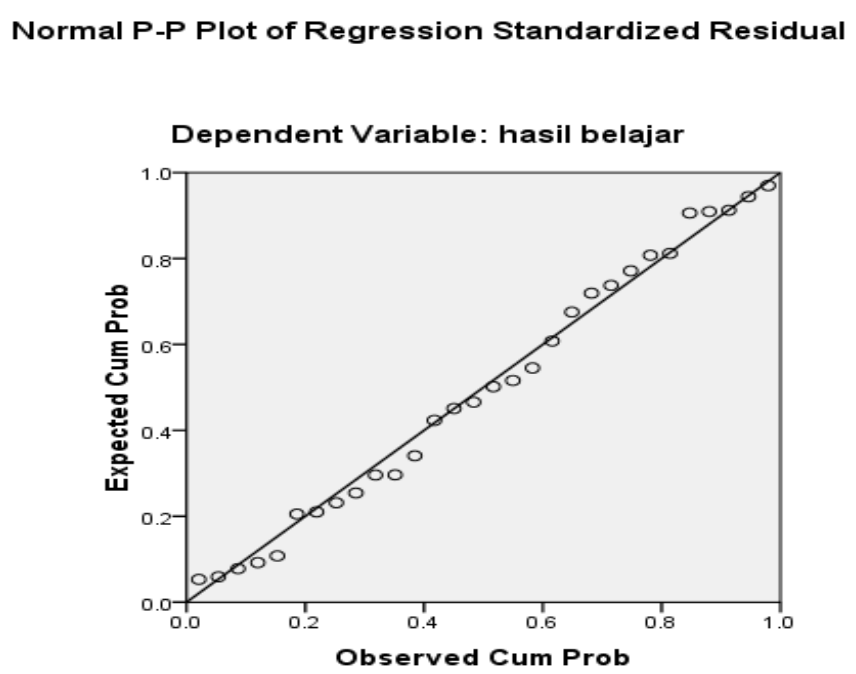

\section{Uji Korelasi}

Uji korelasi bertujuan untuk mengetahui tingkat keeratan hubungan antar variabel yang dinyatakan dengan koefasien korelasi (r). jenis hubungan antar variabel $\mathrm{X}$ dan $\mathrm{Y}$ dapat bersifat positif dan negatif. Dasar pengambilan keputusan dalam uji korelasi yaitu jika nilai signifikansi $\leq 0.005$ dinyatakan berkorelasi. Selanjutnya jika nilai signifikansi $\geq 0.005$ dinyatakan tidak berkorelasi. pedoman untuk melihat tingkat derajat hubungan atau korelasi adalah

1. Nilai person Corellation $0.00 \mathrm{~s} / \mathrm{d} 0.20=$ tidak berkorelasi

2. Nilai person correlation $0.21 \mathrm{~s} / \mathrm{d} 0.40=$ Korelasi Lemah

3. Nilai Pearson Correlation $0.41 \mathrm{~s} / \mathrm{d} 0.60=$ korelasi sedang

4. Nilai pearson correlation $0.61 \mathrm{~s} / \mathrm{d} 0.80=$ korelasi kuat

Hasil uji korelasi kedisplinan guru (Variabel X) terhadap hasil belajar (Variabel Y) adalah dapat di lihat pada tabel di bawah ini.

Correlations

\begin{tabular}{|c|c|c|c|}
\hline & & Kedisplinan guru & hasil belajar \\
\hline \multirow[t]{2}{*}{ Kedisplinan guru } & $\begin{array}{l}\text { Pearson Correlation } \\
\text { Sig. (2-tailed) }\end{array}$ & 1 & $\begin{array}{l}.175 \\
.354\end{array}$ \\
\hline & $\mathrm{N}$ & 30 & 30 \\
\hline
\end{tabular}

Hasil uji korelasi dapat disimpulkan yaitu Kedisplinan guru berhubungan secara positif terhadap hasil belajar dan tingkat derajat hubungan korelasi lemah.

\section{Aplikasi penelitian}

Kedisplinan guru terhadap hasil belajar peserta didik memiliki pengaruh yang yang bernilai positif dan tingkat derajat hubungan korelasi lemah. Untuk itu guru perlu menerapkan dan meningkatkan kedispilinan di sekolah baik untuk guru maupun untuk siswa.

Peserta didik selalu mengikuti teladan yang diterapkan oleh seorang guru. Maka guru adalah sebagai tokoh teladan bagi peserta didik. Dan kedisplinan ini juga dapat mempengaruhi hasil belajar dan lebih dari itu adalah dalam beretika. 


\section{KESIMPULAN}

Berdasarkan hasil penelitian dan analisa data yang dilakukan mengenai pengaruh kedisplinan guru terhdap hasil belajar peserta didik maka dapat disampaikan kesimpulannya yaitu "kedisplinan guru berpengaruh signifikan terhadap peserta didik sesuai dengan hasil uji korelasi bahwa tingkat derajat hubungan berkorelasi lemah dan mempunyai hubungan secara positif."

Kedisplinan guru mempunyai indikator yang menjadi tolak ukur dari pada kedisplinan antara lain: tanggung jawab, tepat waktu pelaksanaan tugas, dan program tidak lanjut. Demikian juga dengan hasil belajar sebagai tolak ukurnya yaitu: daya serap dan pemahaman konsep.

\section{SARAN}

1. Sekolah perlu meningkatkan kedisplinan baik untuk peserta didik maupun untuk guru guna meningkatkan kemajuan sekolah, dalam hal meningkatkan hasil belajar peserta didik dalam mamatuhi setiap aturan dan terlebih pada proses belajar mengajar memiliki daya serap dan pemahaman yang tinggi

2. Orang tua perlu menerapkan kedisplinan untuk anak selama berada di rumah guna membiasakan diri untuk melalukukn setiap kegiatan yang dapat memberikan hasil yang menyenangkan.

\section{KEPUSTAKAAN}

